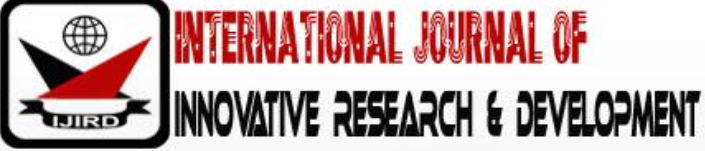

ISSN 2278 - 0211 (Online)

\section{Entrepreneurship Education and Propensity to Start a New Business among College of Education Students' in Ife-North, Osun State, Nigeria}

\author{
Dr. Fola Akinosun \\ Provost, Department of Public Administration \\ College of Education Moro, Ife-North, Osun State, Nigeria \\ Akinosun Olusegun \\ Lecturer, Department of Business Education \\ College of Education Moro, Ife-North, Osun State, Nigeria
}

\begin{abstract}
The aim of the study is to investigate college student's propensity in starting a business through the means of entrepreneurship education. The study used primary data to obtained necessary information from the students. The population size includes 2 institutions in Ife-North, Osun State, Nigeria. A simple random technique was used to select the final year undergraduates from the departments of Business Education, Economics and Political Science.

Data on variables such as entrepreneurial characteristics, entrepreneurship education and entrepreneurial intentions was sourced from the respondents with the questionnaire, and analyzed using descriptive and inferential statistics.

The study showed that entrepreneurial factors influences student's propensity in starting a business and increases their propensity in business start- up, and concluded that entrepreneurship is one of the feasible and viable strategy for reducing unemployment through the means of entrepreneurship education that sharpen student interest in business start- up.
\end{abstract}

Keywords: Entrepreneur, education, intention, propensity, entrepreneurship education

\section{Introduction}

Nigeriahas numerious business and investment potentials due to the abundant, vibrant and dynamic human and natural resources it possesses. Tapping these resources require the ability to identify potentially useful and economically viable fields such as science, technology, academics , business and entertainment, (Agbeze,2012).

According to the International Labour Organisation (ILO, 2007), the increase in the number of youths in secondary and tertiary education is a positive development; however, labourmarkets in many countries, specially Nigeria, are presently unable to accommodate the expanding pool of the skilled young graduates. It is estimated that about 400 million new jobs would be needed to absorb today's youths. (ILO, 2007).

Entrepreneurship is regarded as one of the best economic development strategies to develop a country's economic growth and sustain the country's competitiveness in facing the increasing trends of globalisation (Schaper and Volery 2004; Venkatachalam and Waqif 2005). The popularity of entrepreneurship is largely due to the positive effects it has on many countries as a catalyst that creates wealth and the generation of job opportunities (Postigo and Tamborini 2002; Othman, Ghazali , 2005; Gurol and Atsan, 2006). Nigerian economy shows a high rate of unemployment and underemployment. The rate of open unemployment was 12percent in March 2005; it rose to 19.7 per cent in March 2009 while the rate of underemployment hovered around 19\% in 1998 (Adebayo and Ogunrinola, 2006, NBS 2010). Among the youths in the 15-24 age cohorts, the rate of unemployment is over 40 per cent according to the 2010 edition of the Labour Force Sample Survey of the National Bureau of Statistics. The practice of entrepreneurship education in some countries such as USA, France, Germany, and Britain to mention a few has made entrepreneurial education gain its recognition worldwide.

\subsection{Statement of the Problem}

Entrepreneurship has been globally acknowledged as one of the instruments for achieving economic growth and development as well as employment creation (Rebecca and Benjamen, 2009). This has been given serious attention in many parts of the world, but such cannot be said of Nigeria.

Studies in this area have focused on men and women as adult entrepreneurs, on the informal sector, small, micro and medium sized enterprises (SMMEs), and large firm in the corporate sector. Accordingly, not much is known about potential entrepreneurs among the youths in tertiary institutions and there has been no systematic attempt to look at it from the youth perspective. It is stated that the future of the working environment will depend on the creativity and 
individuality of the young people. In this context, it is of primary important to understand whether entrepreneurship education raises career intention to be entrepreneur generally, or whether it helps the youth determine how suited they are for entrepreneurship. This study therefore appraises entrepreneurship education programme and attempt to find out it impact on self- employment intention of tertiary institution especially the propensity of youth towards entrepreneurship development.

\subsection{Study Objectives}

The specific objectives are to;

- Assess Factors Influencing College Students In Ife-North, Osun State, Nigeria Towards Starting Businesses.

- Examine The Influence Of Entrepreneurship Education On Students' Awareness And Interest In Entrepreneurship Development Among College Students In The Region.

\subsection{Justification of the Study}

This study will help to promote the economy growth and motivate youth in embarking on entrepreneurship skills and training that will equip them to prepare for the labour market after their graduation.The finding of the study hopefully can give some indication on what are the suitable entrepreneurial courses, programs and training that would promote the graduates' interest to start up their own businesses.

\subsection{Scope of the Study}

The study investigates the Students' attitude towards entrepreneurship developement in Ife-North, Osun State, Nigeria. Final year undergraduate students in the college were purposively selected for this study because they are elites who represent the future contributors to the growth and development of the economy and they are educated.

\section{Literature Review}

Entrepreneurship has emerged as an important force in global economic growth. Entrepreneurship as an academic discipline is still considered relatively new although its origin can be traced back to the seventeenth century, when economist Richard Cantillon coined the term, 'entrepreneur' (Cantillon, 1755). The word 'Entrepreneur' originates from the French word 'entreprende' which means 'to undertake'. Earlier it was termed 'UNTERNEHMER'. A word corresponding to this is missing in the English language and literature. The connection of risk with entrepreneurship emerged during the 17th century. An entrepreneur was perceived as a person who entered into a contractual arrangement with the government to perform a service or to supply stipulated products. Since the contract price was fixed, any resulting profits or losses were the entrepreneurs. One entrepreneur in this period was John Law1, a Frenchman, who was allowed to establish a royal bank. (Will and Ariel Durant, 1965). In the 18th century, the person with capital was differentiated from the one who needed capital. In other words, the entrepreneur was distinguished from the capital provider (the present-day venture capitalist). One reason for this differentiation was the industrialization occurring throughout the world. Many of the inventions developed during this time were reactions to the changing world, as was the case with the inventions of Eli Whitney and Thomas Edison (Lakwete, Angela. 2004; Albion, Michele Wehrwein. 2008).

In the late 19th and early 20th centuries, entrepreneurs were frequently not distinguished from managers and were viewed mostly from an economic perspective. Entrepreneurial process is simply the process of transforming idea(s) into a firm. The entrepreneurial process can end in one of two ways. If a feasible solution is found, the firm comes into existence; otherwise, the entrepreneurial process aborts. It is important to distinguish between the success or failure of a firm and the success or failure of the entrepreneurial process.

\subsection{Entrepreneurship Education}

Entrepreneurship education has been recognized as one of the vital determinants that could influence students' career decisions (Kolvereid and Moen 1997; Peterman \& Kennedy, 2003). Whereas according to Chinoso, (2010) technical and vocational education are the only alternative forms of education and training that can guarantee entrepreneurship development and job creation for youths. The definition of entrepreneurship education can be look upon from different scholars. According to Brown (2000) entrepreneurial education is designed to communicate and inculcatecompetencies, skills and values needed to recognizebusiness opportunity, organize and start new businessventure. A good entrepreneurship educationprogramme that are skill-built oriented include; leadership, negotiation, creative thinking, 'exposure to technology, invention and innovation (McMullan and Long,1987; Vesper and McMullen, 1998); opportunityidentification, venture capital, idea generation andprotection, tolerance for ability, ability to tackle challengesat different entrepreneurial stages, personality traits, abilityto write and communicate business plan, new venture development, ability to diagnosis business performance, networking and mentorship, environmental analysis, computer and simulation skills, case studies, films andvideoing, field and company analysis (Zeithamal and Rice1987; Hills 1988; Hood and Young 1993; Donckels, 1991;

Entrepreneurial education alsofocuses on knowledge of small business ownership and self-employment, as well asentrepreneurial skills and attributes.Entrepreneurial education is focused on developing youthwith the passion and multiple skills. It aims to reduce therisk associated with entrepreneurship thought and guide theenterprise successfully through its initial stage to thematurity stage. The entrepreneurial activities create incremental wealth which is a precondition to economic growth. The existence of entrepreneurs and its accelerated growth is a precondition to continuous and sustainable economic growth. The adequate potential for entrepreneurship development as essential qualities are (Innovativeness, risk-taking, perceiving economic opportunities, need for achievement, propensity to risk, 
tolerance of ambiguity, self-confidence.) of an entrepreneur which is available among a good number of people. Given the opportunities and with needed support assistance many can be developed as successful entrepreneurs. The potentials are great; appropriate opportunities provided in congenial environment can help develop entrepreneurship development.

A conceptual Framework of Youth Intention to Entrepreneurship Development.

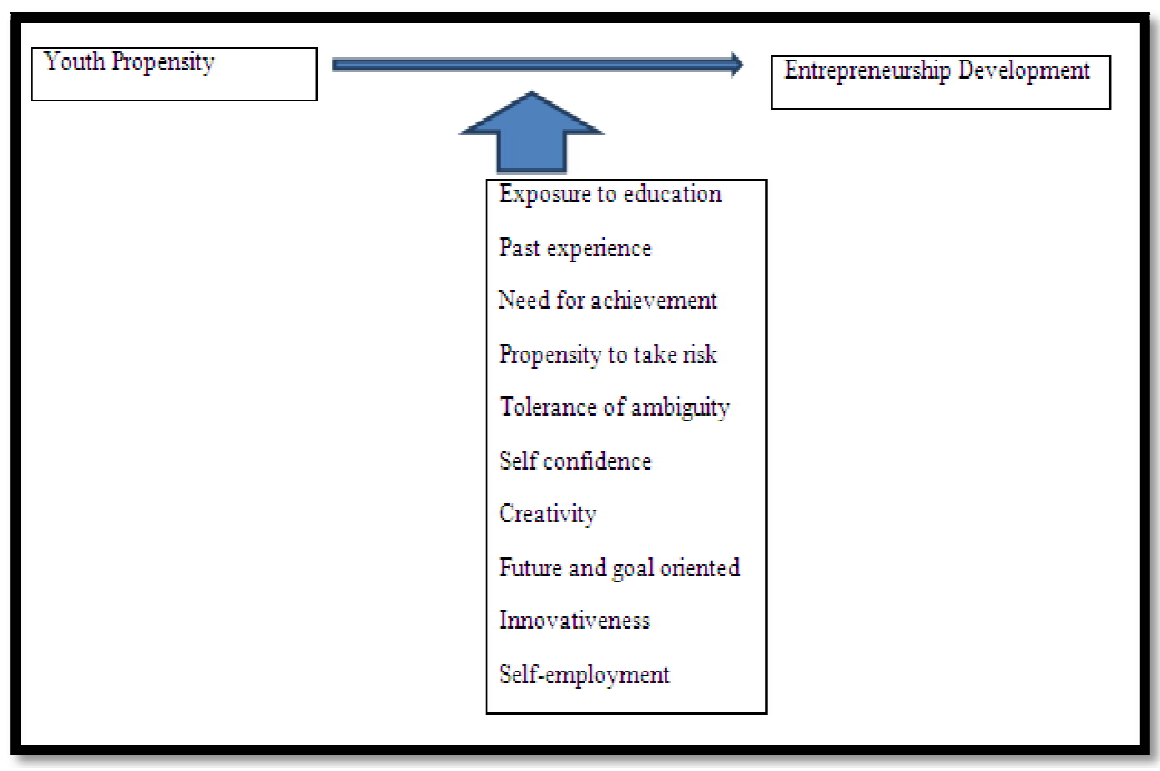

Figure 1

\section{Methodology}

The study was carried out among final year undergraduate student of colleges in Ife-North, Osun State, Nigeria. A descriptive survey research design was used for the study. Population size includes 3 institutions in Ife-North, Osun State, Nigeria. A stratified random technique was used to select 50 final year undergraduates from the departments of Business Education, Economics and Political science totaling 150 respondents. Primary source of data was employed to gathered relevant data using questionnaire. The questionnaires were administered to respondents which are the final year undergraduates' students in the colleges. Data on variables such as entrepreneurial characteristics, entrepreneurial factors, entrepreneurship education and entrepreneurial intentions were sourced from the respondents. Data gathered were analyzed using descriptive and inferential statistics.

\section{Data Analysis and Discussion}

This section examines the profiles of the respondents chosen for the study. Some of the important variable considered included gender, age, tribe, marital status, department, religion, and position in the family.

\begin{tabular}{|c|c|c|}
\hline \multicolumn{3}{|c|}{ Gender Distribution of Respondentsfrequency } \\
\hline Gender & Absolute & Relative (\%) \\
\hline Female & 82 & 54.67 \\
\hline Male & 68 & 45.33 \\
\hline Total & 150 & 100 \\
\hline \multicolumn{3}{|c|}{ Age Distribution of Respondents frequency } \\
\hline Age & Absolute & Relativ (\%) \\
\hline $15-20$ & 27 & 18 \\
\hline $21-25$ & 96 & 63 \\
\hline $26-30$ & 27 & 18 \\
\hline Total & 150 & 100 \\
\hline Distribution of Res] & \multicolumn{2}{|c|}{ Frequency } \\
\hline Department & Absolute & Relative (\%) \\
\hline Business Education & 76 & 50.6 \\
\hline Computer Science & 74 & 49.4 \\
\hline Total & 150 & 100 \\
\hline \multicolumn{3}{|c|}{ Distribution of Respondents by Religion $\quad$ Frequency } \\
\hline Religion & Absolute & Relative (\%) \\
\hline Christain & 95 & 63 \\
\hline Muslim & 55 & 37 \\
\hline Total & 150 & 100 \\
\hline
\end{tabular}

Table 1: Socio-Demographic Characteristics of Respondents

Source: Field Survey, 2018 
Table 4.1, analysis shows that the number of female respondents exceeded that of male, 82 female that is $54.67 \%$ against 68 males' respondents making a percentage of 45.33\%. The description of the respondents by age observed that 27 were below the age group 15-20 years with 18\%, 96 were in between the age group 21-25 years with 63\% while 27 were at the range of 26-30 years with $18 \%$. It also indicated that 108 (50.6\%) of the respondents are from the accounting departments and 106 (49.4\%) are from computer science departments. The description of the respondents by religion as observed in table 4.5 shows that 134 (63\%) are Christian while 80 (37\%) are Muslim.

\subsection{Respondent Entrepreneurial Experience}

The opinion of respondents in relation to business experience they showed that most of them, $72.43 \%$ have sales experience while $27.57 \%$ did not. The study also confirmed that $44.86 \%$ of them have performed supervisory roles while $55.14 \%$ did not. As regards business handling, $42.06 \%$ of has handled one business or the other while $57.94 \%$ have not. Moreover, $12.15 \%$ of them have worked for business owner of small firm (less than 30 workers) while $99.07 \%$ said they have not. In relation to workshop attendance, $16.36 \%$ have attended some formal class or workshop on entrepreneurship while 83.64 said they have not. This is illustrated in the table below

\begin{tabular}{|c|c|c|c|c|}
\hline \multicolumn{5}{|c|}{ Frequency } \\
\hline & Yes & & No & \\
\hline Past Experience & Absolute & Relative\% & Absolute & Relative\% \\
\hline sales experience & 82 & 72.43 & 68 & 27.57 \\
\hline Supervisory role & 96 & 44.86 & 54 & 55.14 \\
\hline Handling business account & 90 & 42.06 & 60 & 57.94 \\
\hline $\begin{array}{c}\text { Running some own business } \\
\text { (excluding family business }\end{array}$ & 78 & 36.45 & 72 & 63.55 \\
\hline $\begin{array}{c}\text { business owner of medium size firm } \\
\text { (less than 200 workers) }\end{array}$ & 3 & 1.40 & 147 & 98.60 \\
\hline $\begin{array}{c}\text { business owner of large firm (more } \\
\text { than 200 workers) }\end{array}$ & 2 & 0.93 & 148 & 99.07 \\
\hline $\begin{array}{c}\text { some formal class or workshop on } \\
\text { entrepreneurship }\end{array}$ & 35 & 16.36 & 115 & 83.64 \\
\hline
\end{tabular}

Table 2: Distribution of Respondents on Entrepreneurial Experience

Source: Field Survey, 2018

\subsection{Analysis of Data according to Study Objectives}

\subsubsection{Factors Influencing Students' Propensity towards Starting Business}

From Table 4.3, respondents were asked to indicate the factors influencing their propensity towards starting a business. The findings show that about 38 per cent of the respondents strongly agree that age increase the drive to start a new business, followed by 35.98 per cent of the respondents that agreed to the statement, 9.8 per cent of the respondents were undecided, 11.2 per cent disagreed to the statement, 5.14 per cent strongly disagreed while the mean value was 1.87

Information from Table 4.3, respondents were also asked if the level of study increases the decision to start a new business, 45.33 per cent of the respondents agreed to this statement, followed by 37,38 percent of the respondents strongly agreed, 6.54 per cent of the respondents disagreed , 5.61 per cent of the respondents strongly agreed , 5.14 per cent of the respondents were undecided while the mean value was 1.97

Information from Table 4.3, shows that 45,8 per cent of the respondents agree that family background influences the decision to start a business, followed by 33.65 per cent of the respondents that strongly agreed to the statement, 7.94 per cent of the respondents were undecided ,7.01 per cent disagreed, 5.61 per cent strongly disagreed to the statement while the mean value was 2.05

Information from Table 4.3, shows that 43.3 per cent of the respondents agree that experience gathered influences the decision to start a business, followed by 42.06 per cent of the respondents that strongly agreed to the statement, 9.4 per cent of the respondents were undecided, 3.27 per cent disagreed, 1.40 per cent strongly disagreed to the statement while the mean value was 1.78 
4.3. Distribution of Factors Influencing Students' Propensity towards Staring Business

\begin{tabular}{|c|c|c|c|c|c|c|c|c|c|c|c|c|c|}
\hline \multirow[t]{2}{*}{ Variables } & \multicolumn{2}{|c|}{ SA } & \multicolumn{2}{|c|}{$\mathbf{A}$} & \multicolumn{2}{|c|}{ UN } & \multicolumn{2}{|c|}{ D } & \multicolumn{2}{|c|}{ SD } & \multirow[t]{2}{*}{ Total } & \multirow{2}{*}{$\begin{array}{l}\text { Mean } \\
\text { Score } \\
\bar{x} \\
\end{array}$} & \multirow[t]{2}{*}{ Rate } \\
\hline & $\mathrm{F}$ & $\%$ & $F$ & $\%$ & $\mathrm{~F}$ & $\%$ & $\mathrm{~F}$ & $\%$ & $\mathrm{~F}$ & $\%$ & & & \\
\hline $\begin{array}{c}\text { Age increase the } \\
\text { drive to start a new } \\
\text { business }\end{array}$ & 81 & 37.85 & 77 & 35.98 & 21 & 9.81 & 24 & 11.21 & 11 & 5.14 & 150 & 1.87 & SA \\
\hline $\begin{array}{c}\text { Level of study } \\
\text { increase the tendency } \\
\text { to start a new } \\
\text { business }\end{array}$ & 80 & 37.38 & 97 & 45.33 & 11 & 5.14 & 14 & 6.54 & 12 & 5.61 & 150 & 1.97 & $\mathrm{~A}$ \\
\hline $\begin{array}{c}\text { Social and } \\
\text { communication skills } \\
\text { contribute to the } \\
\text { tendency to start a } \\
\text { new business }\end{array}$ & 62 & 28.97 & 95 & 44.39 & 23 & 10.75 & 18 & 8.41 & 16 & 7.48 & 150 & 2.21 & A \\
\hline $\begin{array}{l}\text { Family background } \\
\text { influences the } \\
\text { decision to start a } \\
\text { business }\end{array}$ & 72 & 33.65 & 98 & 45.79 & 17 & 7.94 & 15 & 7.01 & 12 & 5.61 & 150 & 2.05 & $\mathrm{~A}$ \\
\hline $\begin{array}{l}\text { Experience gathered } \\
\text { influences to start a } \\
\text { business }\end{array}$ & 90 & 42.06 & 94 & 43.93 & 20 & 9.35 & 7 & 3.27 & 3 & 1.40 & 150 & 1.78 & $\mathrm{SA}$ \\
\hline $\begin{array}{l}\text { Grand Total Mean } \\
\text { Score }\end{array}$ & 462 & & $\begin{array}{c}57 \\
2\end{array}$ & & $\begin{array}{c}11 \\
2\end{array}$ & & 83 & & 55 & & 1284 & & \\
\hline Grand Total \% & & 216 & & 267 & & 52 & & 39 & & 26 & 600 & & \\
\hline
\end{tabular}

Table 3: Distribution of Factors Influencing Students' Propensity towards Staring Business

Strongly Agree $\mathrm{SA}=1$, Agree A =2, Undecidl UN=3, Disagree $\mathrm{D}=4$, Strongly Disagree $\mathrm{SD}=5$

Source: Field Survey, 2018

\subsubsection{Contingency Table on Influence of Entrepreneurship Education on Propensity to Start a New Business}

\begin{tabular}{|c|c|c|c|c|c|c|}
\hline Rate your level of interest in starting your business & & & & & & 150 \\
\hline What spur your interest in starting a business & 45 & 54 & 72 & 30 & 13 & 150 \\
\hline $\begin{array}{c}\text { I perform well in the written exams on } \\
\text { entrepreneurship }\end{array}$ & 65 & 66 & 32 & 39 & 12 & 150 \\
\hline I have gone for a training on how to start a business & 59 & 61 & 30 & 45 & 19 & 150 \\
\hline Total & 241 & 264 & 160 & 131 & 60 & 750 \\
\hline
\end{tabular}

Table 4

Source, Field Survey, 2018

The table above shows influence of Entrepreneurship Education on Propensity to start a new Business. Observed frequencies with their expected are shown in the table below.

To get the expected value, this is Row Total * Column Total / Grand Total

\begin{tabular}{|c|c|c|c|c|c|c|}
\hline $\begin{array}{c}\text { Rate your level of interest in } \\
\text { starting your business }\end{array}$ & $72(60.25)$ & $83(66)$ & $26(40)$ & $17(32.75)$ & $16(15)$ & 150 \\
\hline $\begin{array}{c}\text { What spur your interest in } \\
\text { starting a business }\end{array}$ & $45(60.25)$ & $54(66)$ & $72(40)$ & $30(32.75)$ & $13(15)$ & 150 \\
\hline $\begin{array}{c}\text { I perform well in the written } \\
\text { exams on entrepreneurship }\end{array}$ & $65(60.25)$ & $66(66)$ & $32(40)$ & $39(32.75)$ & $12(15)$ & 150 \\
\hline $\begin{array}{c}\text { I have gone for a training on } \\
\text { how to start a business }\end{array}$ & $59(60.25)$ & $61(66)$ & $30(40)$ & $45(32.75)$ & $19(15)$ & 150 \\
\hline Total & 241 & 264 & 160 & 131 & 60 & 750 \\
\hline
\end{tabular}

Table 5: Distribution of Frequency and Expected of the respondents

Source: Field Survey, 2018 
The Chi-Square formula is $\mathrm{x}^{2}=\sum(\mathrm{Fo}-\mathrm{Fe})^{2} / \mathrm{Fe}$

Where; $\mathrm{x}^{2}$ is the value of chi- square calculated, fo is observed frequencies, fe is expected frequencies, Therefore, $\mathrm{x}^{2}=$ 63.51

Degree of freedom is [r-1][c-1], in which row is 5 and column is $4=[5-1] \quad[4=12$

At 0.05 significant levels, the critical value is 21.226 .

Decision: since the calculated value is greater than critical value (F 12, 21.226 $=63.51, \mathrm{P}<0.05$

We accept the statement that 'Entrepreneurship Education has influence on Student Interest and Awareness'.

\section{Conclusion}

Since, entrepreneurship is one of the feasible and viable strategies of reducing unemployment all over the globe, and which serve as a catalyst to economic growth and development in the country, the need for entrepreneurship education cannot be over- emphasized. Entrepreneurship education is widely accepted and very important that there is urgent need for all higher educational institutions in Nigeria to comply with the presidential directives to the effect that entrepreneurship be made compulsory for all students of higher education institutions in Nigeria, irrespective of their areas of specialization, as it enables students in taking advantage of their knowledge in a business, whether in an established one or a start-up.

\section{Recommendations}

Based on the findings of the study, it is shown from the findings that more sufficient facilities should be provided to support the universities in promoting entrepreneurship education by funding them technically. More so, there should be a constant review of entrepreneurship curriculum by the Nigeria Universities Commission (NUC) in which would still be required in the way of helping undergraduates to cultivate entrepreneurial mind-set through some of the courses to which they would be exposed to in the university.

\section{References}

i. Adebayo, A. (1999). "Youth unemployment and the National Directorate of Employment, Self-employment programmes". The Nigerian Journal of Economic and Social Studies, 41(1).

ii. Adetayo, E. (1998). "Entrepreneurial Performance of Micro Scale Food Processing Industries in Osun State, Nigeria". Ph.D. Dissertation, Obafemi Awolowo University, Ife, Nigeria.

iii. Adetayo, E. D, Fayomi, I., and Oribabor, P. (1999). "Entrepreneurial Development in Tertiary Institutions: A Strategy for Self-employment", Journal of Behavioural Research, Obafemi Awolowo University, Ife, Nigeria.

iv. Adetayo, E. D. (2001). Business Research. Obafemi Awolowo University Press Limited. Ile-Ife, Nigeria. 1st edition.

v. Bakotic, D. and Kruzic, D. (2010). "Students' perceptions and intentions towards entrepreneurship: the empirical findings from Croatia". The Business Review, 14(2):209-215.

vi. Bandura, A. (1977). Social Learning Theory, Prentice Hall, Englewood Cliffs, NJ.

vii. Bandura, A. (1986). Social foundation of thought and action: A social cognitive theory. Englewood Cliffs, NJ: Prentice Hall.

viii. Casson, M. (1982). Transaction costs and the theory of the multinational enterprise. In A.M. Rugman (ed.) "New Theories of the multinational enterprise", St. Martin's press, New York.

ix. Cantillion, R. (1755)” Essai sur la Nature du Commerce en General, H. Higgs (ed.), (1931) Macmillan, London.

x. Carsrud, A. L. and Johnson, R.W. (1988). "Entrepreneurship : A Social Psychology Perspective. Working Paper, USC Entrepreneur Program, University of Southern California, Los Angeles.

xi. Chigunta, F. (2002). The Socio-economic Situation of Youths in Africa: Problems, Prospects and Options. A Paper Presented at the Youth Employment Summit, Alexandria, Egypt. pp. 1 -13.

xii. Casson, M. (1982). Transaction costs and the theory of the multinational enterprise. In A.M. Rugman (ed.) "New Theories of the multinational enterprise," St. Martin's press, New York.

xiii. Chandler, G.N. (1996). Business similarity as a moderator of the relationship between pre-ownership experience and venture performance. Entrepreneurship: Theory and Practice, 20(3), 51-65.

xiv. Charney, A. and Libecap, G. (2000). The Impact of Entrepreneurship Education, Insights: A Kauffman Research Series, 1 - 9 .

xv. Cheston, S. and Kuhn, L. (2002)" Empowering women through microfinance. A case study of Sinapi Aba Trust, Ghana USA: Opportunity International.

xvi. Davidsson P. (1995). "Culture, structure and regional levels of entrepreneurship". Entrepreneurship Reg Development 7(1):41-62.

xvii. Davidsson, P. (1995). “Determinants of Entrepreneurial Intentions. In Proceedings REN XI Workshop, Piacenza, Italy. http:/ / eprints.qut.edu.au/ archive/ 00002076/ Retrieved on Sept. 2007.

xviii. Deakins, D., K. Glancey, et al. (2005). "Enterprise education: The role of Head Teachers." International Entrepreneurship and Management Journal 1: 241-263.

xix. Douglas, E.J. and Shepherd, D.A. (2002). "Self-employment as A Career Choice: Attitudes, Entrepreneurial Intentions and Utility Maximization', Entrepreneurship Theory and Practice,"Vol. 26, no. 3, pp.81-90.

xx. Douglass, M.E. (1976). Relating education to entrepreneurial success. Business Horizons, 19(6), 40-44.

xxi. Dyer, W.G, Jr. (1994). Toward a theory of entrepreneurial careers. Entrepreneurship Theory and Practice, 19(2), 7-21. 
xxii. Emeraton, U.G. (2008). Re-thinking Higher Education Management for Poverty Reduction among the Youth in Africa. Paper Presented at the Third Regional Conference Higher Education for Youth Empowerment, Opportunities, Capabilities and Second Chance. Organized by Higher Education Research and Policy Network (NERPNET) at IITA, Ibadan, Oyo State. August 18-21.

xxiii. Egboh, E.A., M.A. Obi, M.I. Okeke, and O.I. Eme. (2009). Rural and Community Development: Critical Issues and Challenges, Onitsha: Austino Publishing Company.

xxiv. Encyclopedia Americana, (1988), "Managing emotional fallout remarks from America's Top psychiatrist", Harvard Business Review, February, P. 34-40.

xxv. Foley, A. and B. Griffith. (1998). "Education, training and the promotion of high-quality entrepreneurs in Republic of Ireland", in M Scott, P Rosa, \& H Klandt (Eds.), Educating entrepreneurs for wealth creation. Brookfield, VT: Ashgate Publishing Company.

xxvi. Fayolle, A. G. and B. Gailly (2005). Using the Theory of Planned Behaviour to assess entrepreneurship teaching programmes, Centre for Research in Change, Innovation and Strategy: 1-18.

xxvii. Fayolle, A. and J.M. Degeorge. (2006). "Attitudes, intentions, and behaviour: New approaches to evaluating entrepreneurship education", in A Fayolle \& H Klandt (Eds.), International 